\title{
Dietary contribution of Wild Edible Plants to women's diets in the buffer zone around the Lama forest, Benin - an underutilized potential
}

\author{
Julia Boedecker • Céline Termote • Achille Ephrem Assogbadjo • \\ Patrick Van Damme • Carl Lachat
}

Received: 5 March 2014 / Accepted: 2 October 2014 /Published online: 21 October 2014

(C) The Author(s) 2014. This article is published with open access at Springerlink.com

\begin{abstract}
Rural populations in developing countries face food insecurity and malnutrition despite being surrounded by extraordinary biodiversity. The international community increasingly recognizes the role of agro-biodiversity and Wild Edible Plants (WEPs) in their contributions to managing risk and building resilience and sustainable food systems. Studies on real contributions of WEPs to peoples' diets, however, are uncommon. This study assessed the contribution of WEPs to diets of women living in the buffer zone of the Lama forest in southern Benin. During the long dry season, a cross-sectional survey was carried out on 120 women, covering their knowledge and attitudes
\end{abstract}

J. Boedecker $\cdot$ C. Termote $\cdot$ P. Van Damme

Laboratory of Tropical and Subtropical Agronomy and Ethnobotany,

Ghent University, Coupure links 653, 9000 Ghent, Belgium

J. Boedecker

e-mail: die_juja@gmx.de

P. Van Damme

e-mail: patrick.vandamme@UGent.be

\section{A. E. Assogbadjo}

Laboratory of Applied Ecology, Faculty of Agronomic Sciences, University of Abomey-Calavi, 01BP526 Cotonou, Benin

e-mail: assogbadjo@gmail.com

C. Lachat

Department of Food Safety and Food Quality, Ghent University, Coupure links 653, 9000 Ghent, Belgium

e-mail: Carl.Lachat@UGent.be

\section{Lachat}

Nutrition and Child Health Unit, Institute for Tropical Medicine, Nationalestraat 155, 2000 Antwerpen, Belgium

Present Address:

J. Boedecker $\cdot$ C. Termote $(\square)$

Nutrition and Marketing Diversity Programme, Bioversity International, Via dei Tre Denari, 472/a, 00057 Maccarese/Rome, Italy

e-mail: celinetermote@hotmail.com towards WEPs and two non-consecutive 24-h recalls of their WEP consumption. Contribution of WEPs to total dietary intake was low due to infrequent use and small portion sizes. The highest nutrient contributions of WEPs measured were for copper $(13.9 \%)$ and iron (4.6\%) but the majority of the women had intake values below the Estimated Average Requirements (EARs) for these elements - copper $65 \%$ and iron $91 \%$ Women's dietary diversity was significantly higher among WEP consumers than non-consumers, mainly due to higher consumption of dark green leafy vegetables. WEPs were less consumed as a replacement for other foods but rather as a complement to the diet. The study population generally appreciated WEPs, while some constraints were reported regarding preparation, conservation and commercialization. Before widely promoting WEP consumption in order to exploit their dietary potential, additional investigations are needed into their nutrient composition, cultural and market value, their sustainable harvest levels and possible integration into innovative farming systems.

Keywords Wild edible plants · Nutrition · Biodiversity · Dietary diversity

\section{Introduction}

Sub-Saharan Africa, with close to 223 million people (24.8\%) undernourished, remains the world's most food-insecure region (FAO 2013a). Meanwhile, the continent exhibits highly biodiverse environments with valuable, but often neglected and underutilized resources such as Wild Edible Plants (WEPs) (Chennai Platform for Action 2005). According to Heywood (1999) and Termote et al. (2011), WEPs are defined as 'plants that are gathered (not cultivated), which grow spontaneously in self-maintaining populations in natural or semi-natural ecosystems and can exist independently of direct human action'. 
In resource-poor settings worldwide, low-quality, monotonous diets are common and the risk of micronutrient deficiencies is high (Arimond et al. 2010; FAO 2013b). At the same time, global supply of food energy is dependent on only a small number of cultivated species and varieties (Barucha and Pretty 2010; FAO 2013a; Grivetti and Ogle 2000). Food security is often seen as the amount of energy available from staple food production, but the quality of diet in terms of range of nutrients and food components is not taken into account. Together with the lack of food composition data on WEPs, this has led to a routine undervaluation of WEPs in diets and to their neglect by researchers, policy makers and nutritionists (Grivetti and Ogle 2000; Figueroa et al. 2009).

Recently, the study of biodiversity, encompassing cultivated and wild biodiversity, has become part of the agriculture, food and nutrition agenda (Barucha and Pretty 2010). There is now greater attention paid to the role of WEPs as part of agrobiodiversity in managing risk, building resilience and supporting household subsistence (Mahapatra and Panda 2012). WEPs can contribute to food security in several ways. Harvesting and trading WEPs can result in rural employment and income generation (Shackleton and Shackleton 2004; Akinnifesi et al. 2005; Keller et al. 2006; Agea et al. 2007; Barucha and Pretty 2010; Legwaila et al. 2011). In other studies, the incorporation of WEPs in cropping systems has increased agro-biodiversity, enhanced production and mitigated the effects of environmental shocks, pests and diseases (Moore and Raymond 2006; Tilman et al. 2006; Venter et al. 2007; Frison et al. 2011; Mahapatra and Panda 2012; Asif and Kamran 2013). Furthermore, WEPs are adapted to the local and sometimes harsh environmental conditions where other cultivated species would fail (Bradford 2010; Flyman and Afolayan 2006). Because of their resilience, WEPs can act as safety nets in times of food shortage and famine (Guinand and Dechassa 2000; Shackleton and Shackleton 2004; Kebu and Fassil 2006; Keller et al. 2006). They may also contribute to greater dietary diversity and be essential components of an otherwise monotonous and nutritionally poor diet (Grivetti and Ogle 2000; FAO 2005; Fentahun and Hager 2009). A number of authors stress the high nutritional (micronutrient) content of WEPs (Nesamvuni et al. 2001; Steyn et al. 2001; Odhav et al. 2007; Kuhnlein et al. 2009; Mavengahama et al. 2013). Lastly, WEPs, in some cases, also represent an inextricable link between people and their lands, defining bio-cultural identity (Barucha and Pretty 2010).

Various researchers have argued that WEPs are important in local food systems and make significant contributions to the food and nutrition security of the poor (Lockett et al. 2000; Mahapatra and Panda 2012; Mavengahama et al. 2013; Fentahun and Hager 2009; Legwaila et al. 2011; Shackleton 2003). However, studies actually quantifying the contributions of WEPs to diets are scattered and use different methodologies, making comparisons difficult. Few studies have assessed the real contribution of WEPs to energy and nutrient intake by thorough dietary assessment methods (Grivetti and Ogle 2000; Penafiel et al. 2011; Mavengahama et al. 2013; Powell et al. 2013). They include those by Ogle et al. (2001ac) in Vietnam, Termote et al. (2012) in DR Congo and Powell et al. (2013) in Tanzania but the authors arrive at divergent results and conclusions. More research is thus needed to better understand the different roles and potential of WEPs in agricultural systems, diets and nutrition within different agroecological, economic and socio-cultural contexts. This becomes even more important, given that increasing modernization and globalization have been reported as factors contributing to the loss of knowledge and decline in the use of WEPs, leading to changes in dietary patterns (Keller et al. 2006).

Up till now, several ethnobotanical studies in (Southern) Benin have documented a vast number of WEPs known by the local populations (Achigan-Dako et al. 2010 and 2011; Dansi et al. 2008; N'Danikou 2009; N'Danikou et al. 2011), but none has attempted to quantify their dietary contributions using thorough food intake assessment methods. The objective of this study is to assess the contribution of WEPs to women's diets in the buffer zone of the Lama forest in southern Benin, a plant biodiverse region diversity (Djego 2003; N'Danikou 2009). It describes the overall dietary patterns of the women there, evaluates their total dietary intake against the Estimated Average Requirements (EARs) of adult women and documents the contribution of WEPs to energy, macronutrient and micronutrient intakes as percentages of total nutrient intake. Furthermore, local women's attitudes towards WEPs were analyzed, such as whether WEPs were nutritious, 'food for the poor' or part of cultural practices. To our knowledge, this is the first study combining both an assessment of the contributions of WEPs to diets as well as local attitudes towards them. This should help to identify determinants of WEP consumption and contribute to a better understanding of the links and gaps between traditional knowledge, attitudes and actual use of WEPs .

\section{Materials and methods}

All research protocols and questionnaires were developed in collaboration with and evaluated by the University of AbomeyCalavi in Benin. In addition, ethical clearance was obtained from the Ethical Committee of Ghent University, Belgium (registration number: B670201112730). Because most rural women in the Lama forest are illiterate, the study protocol and the likely findings were explained in their local language to community leaders and respondents and informed oral consent was obtained from all participants before starting the interviews.

Study site and population

The research was carried out in the buffer zone around the Lama forest, which is situated about $80 \mathrm{~km}$ north of Cotonou. 
With 16,250 ha, the Lama forest belongs to the last and largest forest remnants of the Dahomey Gap, a semiarid zone that meets the coast around the Ghana-Togo-Benin-Nigeria borders (Nagel et al. 2004). The Lama forest has been legally protected since 1946 as a classified forest, which implies prohibition to enter its core and therefore limited access to certain WEPs for local populations. However, many WEPs also grow in the buffer zone and near residential areas. Holli, Fon and Aizo ethnic groups inhabit the forest but the present research is focused on the Holli group as they are the dominant group (Nagel et al. 2004).

\section{Study sample}

The sample comprised non-pregnant and non-lactating women older than 18 years. Women were chosen because they are the primary decision-makers for food preparation in Benin and are also considered to be a vulnerable group with regard to food and nutrition security. Collecting food intake data from men would introduce error as men typically do not know the exact composition of most of the dishes they consume. Pregnant and lactating women were excluded from the sample as their energy and nutrient needs are different from those not in these conditions.

Interviews took place in the respondents' homes between mid-February and mid-March 2012 during the long dry season. In total, 120 women from the Holli ethnic group were interviewed. Women were randomly selected from two out of the three villages of the Lama forest, Agadjaligbo and Zalimé, which were chosen for their accessibility. Households were randomly selected according to the random walk method (UNICEF 2010). The interviewers started from a crossroads in each village. One of the four paths leading from the cross was chosen and the first household was visited. In case of absence, the household next door was visited. About 15 interviews were conducted along each of the four paths, always starting from the crossroads. In both villages, 60 interviews were carried out.

Data were collected by two graduate agronomy students from the University of Abomey-Calavi in Cotonou and a local guide with a secondary school degree. All spoke the local language and were experienced in data collection in the Lama forest. Training and supervision of data collection was undertaken by the first author (JB). Uniform translations of the questionnaires in local languages were agreed upon among the students and the local guide. All questionnaires and tools were pre-tested and adapted where necessary.

\section{Questionnaire}

The questionnaire comprised three parts. The first part dealt with socio-economic information about the women, including age, marital status, ethnic group, activities, number of household members and possession of a field or garden. The second part covered the respondent's WEP knowledge as well as attitudes and constraints to WEP consumption. Attitudes towards WEPs were assessed using yes/no questions and 5point Likert scales (ranging from 'I strongly disagree' $(-2)$ over 'I disagree' (-1), 'neutral' (0), 'I agree' (1) to 'I strongly agree' (2)). Open questions were used to ask about constraints. The third part assessed food intake of the respondents by two interactive 24-h recalls carried out on non-consecutive days (Jonnalagadda et al. 2000; Sodjinou et al. 2009). Portion sizes were estimated using a village specific price-weight conversion list as well as a variety of different spoons, plastic cylinders and a selection of local utensils to help the respondents in estimating the quantities of foods or ingredients consumed (Gibson and Ferguson 2008). In addition, two digital scales (Soehnle, Nassau, Germany, precision $1 \mathrm{~g}$ ) were used to weigh leftovers where available.

To compose the price-weight conversion lists, edible parts of raw foods available at the local market of each village were weighed five times per food and per price unit to calculate an average price-weight conversion factor. Nutrient values of most foods in the used Food Composition Table (FCT) are those of the edible parts of raw foods. Thus the conversion factors reflect the weights of edible parts of raw foods for each village. Individual recipes were recorded when possible. Only if a dish were consumed outside the home were average recipes used. Average recipes were recorded from observed preparation processes of food sold at the market by a sample of women. Each dish was prepared separately by several women in order to obtain the average. All raw ingredients were listed and their edible parts weighed. The total weight of the prepared dish was registered and the weight of each raw ingredient was calculated as a percentage of the total cooked weight of the dish. As each dish was prepared several times, an average of the percentage weights of the raw ingredients could be used to calculate the average recipe of a certain dish.

\section{Food composition table}

There is no national FCT for Benin. To convert ingredients into their nutrient levels, the West African FCT (Stadlmayr et al. 2011) was used. Nutrient data for foods that were not found in this table were completed by using other sources including: the Mali FCT (Barikmo et al. 2004), the FAO FCT from 1968 (Leung et al. 1968) and the USDA nutrient database (http://ndb.nal.usda.gov/ndb/search/list, accessed July 2012). Information from the following studies was used for nutrient values of specific WEPs: Nordheide et al. (1996; Parkia biglobosa), Ulmar et al. (2007; Ipomoea aquatica), Oboh (2006; Struchium sparganophorum) and Oladejo (2009; Dialium guineense). Nutrient values that were still lacking were replaced by data on similar foods in the FCT. When needed, nutrient contents of raw foods were corrected for cooking processes according to the USDA guidelines (USDA 2007). 
Species identification

WEPs were identified in the field with the lexicon "Flore du Bénin" (Akoègninou et al. 2006). Dried specimens and pictures of plants that could not be identified in the field were taken to the National Herbarium of the University of Abomey-Calavi. Some WEPs cited by the participants were not available due to seasonality, whereas a few others were inaccessible due to legal restrictions in the forest. All species names were verified on the Missouri botanical garden (www.tropicos.org) and the International Plant Names Index website (www.ipni.org) and classified into botanical families according to the APGII system.

\section{Data analysis}

Food intake data from the two 24-h recalls were entered and processed in the Lucille analysis software (Ghent University, Belgium, www.foodintake.ugent.be). In addition, each food consumed was labeled as wild food or non-wild food. Usual food group and nutrient intake distributions were generated by means of the Multiple Source Method (MSM) (EFCOVAL 2010; Haubrock et al. 2011). This method allows elimination of intrapersonal variation of the intake of the nutrient/food group. The distributions generated were adjusted for 'interviewer'. Usual daily nutrient intakes were calculated for total intake and for WEP intake alone. Percentages of women with micronutrient intakes below the estimated average requirement (EAR) were calculated. The EAR is the average daily nutrient intake estimated to meet the needs of half the healthy individuals in a particular age and gender group (FAO/WHO 2004). When FAO/WHO EAR values were not available, EAR values from Health Canada were used (Health Canada 2011). The lowest bioavailability for zinc (15\%) and iron (5\%) were used as the recorded diets were predominantly plant based (Gibson and Ferguson 2008). Dietary diversity was evaluated, based on the Women Dietary Diversity Score (WDDS), and reported as the mean number of food groups (out of nine in total) consumed during the previous day by women of reproductive age (FAO 2010).

To assess the nutritional contribution of WEPs, the sample was split into two groups: WEP consumers (having consumed WEPs in at least one 24-h recall) and non WEP consumers. Data were analyzed in SPSS version 21. ANOVA was used to compare the usual energy and nutrient intakes as well as the usual amounts of food groups eaten between WEP consumers and non WEP consumers. Comparison of micronutrient intakes were adjusted for total energy intake. Chi-square $\left(\chi^{2}\right)$ tests were used to compare proportions of WEP consumers and non WEP consumers consuming different food items and food groups. Statistical significance was set at $\alpha=5 \%$ for all statistical tests.

\section{Results}

Respondent characteristics

The respondent characteristics are presented in Table 1. The majority of the households (91 \%) sometimes collected WEPs, either exclusively for home consumption or for both home consumption and sale. All households owned a piece of land where they grew food and the majority of the women possessed a home garden (69\%). Almost all respondents (98\%) reported that at least one person in the household lacked food at a certain period of the year, mainly during the long dry season (December-March). After the interviews, one woman appeared to be pregnant and five women were lactating. They were excluded from further diet analyses, but included during analyses of knowledge, attitudes and barriers towards WEP consumption.

The respondents reported high levels of physical activity ( $41.2 \%$ and $55.2 \%$ of the women reported very high levels of physical activity for the first and second recall day, respectively, corresponding with increased agricultural activities at the end of the dry season).

\section{Contribution of WEPs to the diet}

\section{Typical diet in the Lama forest}

The diet is mainly based on a solid mash of maize flour and water, which was consumed with a sauce based on palm oil, salt, onions, garlic, tomatoes, dried chili peppers and bouillon. Additionally these sauces may include fish, green leafy vegetables or beans. Fruit consumption was low, meat consumption very rare and the consumption of eggs and milk/milk products even more uncommon. Groundnuts were a typical snack.

\section{WEP knowledge versus consumption}

Each woman could list on average 13 WEPs. All participants together knew a total of 61 different WEPs of which 48 could be botanically identified (Table 2). The 61 WEPs comprised 22 species from which the leaves can be consumed as vegetables, 31 species of which the fruits can be consumed as fruits or nuts, 4 species with edible tubers which can be used as staples and 5 species from which the bark can be used as spices ( 1 species can be consumed as a tuber and/or spice). Only 8 of the 61 WEPs known were actually recorded as being consumed the previous day in one or more of the $220^{1}$ recalls performed, namely the leafy vegetables Struchium sparganophorum, Vitex doniana, Ipomoea aquatica,

\footnotetext{
${ }^{1} 6$ women were excluded from this analyses and for 8 other women, we did not obtain the 2 nd $24 \mathrm{~h}$ recall
} 
Table 1 Socio-demographic characteristics of the sample

\begin{tabular}{|c|c|}
\hline Characteristics & Sample $n(\%)$ \\
\hline Total number of subjects & $120(100)$ \\
\hline Number of subjects in Agabogmey & $60(50)$ \\
\hline Number of subjects in Zalimé & $60(50)$ \\
\hline Mean age ${ }^{a}$ & $38.9 \pm 12.3$ \\
\hline Pregnant & $1(0.8)$ \\
\hline Lactating & $5(3.3)$ \\
\hline \multicolumn{2}{|l|}{ Education } \\
\hline Not educated & $112(93.3)$ \\
\hline Primary school & $5(4.2)$ \\
\hline Secondary school & $2(1.7)$ \\
\hline Higher education & $1(0.8)$ \\
\hline \multicolumn{2}{|l|}{ Marital status } \\
\hline Single & $4(3.3)$ \\
\hline Married (1st wife) & $89(74.2)$ \\
\hline Married (2nd or 3rd wife) & $21(17.5)$ \\
\hline Widow & $5(4.2)$ \\
\hline \multicolumn{2}{|l|}{ First activity } \\
\hline Agriculture & $101(84.2)$ \\
\hline Animal breeding & $12(10)$ \\
\hline Other & $7(5.8)$ \\
\hline Household members $^{\mathrm{a}}$ & $7.8 \pm 4.1$ \\
\hline \multicolumn{2}{|l|}{ Agricultural activities of the household } \\
\hline Animal breeding & $115(95.8)$ \\
\hline Fishing & $64(53.3)$ \\
\hline Hunting & $13(10.8)$ \\
\hline Collection of WEPs & $109(90.8)$ \\
\hline For own consumption & $61(50.8)$ \\
\hline For sale & $0(0)$ \\
\hline For own consumption and sale & $48(39.9)$ \\
\hline Women owning a garden & $83(69.2)$ \\
\hline Women owning source of electricity & $34(28.3)$ \\
\hline Lack of food in certain period of the year & $115(97.5)$ \\
\hline
\end{tabular}

${ }^{\mathrm{a}}$ Mean with standard deviation

Alternanthera sessilis, Celosia argentea and Amaranthus spinosus; the fermented seeds of Parkia biglobosa; and the fruit, Dialium guineense.

The consumption frequency of wild species is shown in Fig. 1. In total, $37 \%$ of the recalls contained at least one WEP. The mean usual WEP portion accounts for 21.7 g. Parkia biglobosa was by far the most consumed WEP and was present in $18 \%$ of the recalls. Parkia biglobosa seeds, called néré, are fermented into a condiment called "soumbala" before being added to sauces in rather small quantities. Struchium sparganophorum was found in $5 \%$ of the recalls.

Table 3 presents the consumption of food group/items for WEP consumers and non WEP consumers. Overall, the consumption patterns did not differ substantially between the groups. The proportions of respondents consuming green leafy vegetables and dried fish were significantly higher among WEP consumers compared with non WEP consumers $(P<0.001$ and $P=0.001$, respectively). The quantities consumed of the 6 respective food groups (Table 4 ), were slightly higher for WEP consumers than for non consumers except for 'other fruits and vegetables'. A significant difference existed for dark green leafy vegetables $(P<0.001)$.

\section{Dietary diversity}

The calculation of the WDDS takes into account nine food groups out of which six were consumed by our sample women. WEPs were present in 3 out of the 6 foods groups ('dark green leafy vegetables', 'other fruits and vegetables' and 'legumes, nuts and seeds') (Table 3). The difference between the WDDS of WEP consumers (5.1) and non consumers (4.5) is highly significant $(P<0.001)$ (Table 4$)$. This can be attributed to a higher percentage of women consuming foods in the green leafy vegetables group due to consumption of wild species in this group (Table 3).

\section{Micro- and macronutrient intake of the respondents}

Table 5 shows the total daily median energy and nutrient intakes with the percentage of women below the EAR values. For 10 out of the 16 micronutrients, median intake values were below the EAR values. Nutrients with a very high proportion of women below the EAR include iron (91\%), Vitamin B-12 (87 \%) and copper (65\%).

\section{Contribution of WEPs to macronutrient intake}

Table 5 presents the median daily energy and nutrient intakes from WEPs. The median daily energy intake from WEPs and the contributions to the macronutrients were very small.

\section{Contribution of WEPs to micronutrient intake}

WEP contributions to total daily micronutrient intakes were small (Table 5). The highest contributions were found for copper $(13.9 \%)$, iron $(4.6 \%)$, calcium $(2.6 \%)$, riboflavin (2.5\%) and Vitamin C (2.3\%). The high contribution to copper intake came from the consumption of the green leafy vegetables, Vitex doniana and Celosia argentea, which are rich in copper, and the frequent consumption of the condiment "soumbala".

Table 6 shows the median energy/nutrient intakes of WEP consumers and non WEP consumers and the proportion of women from both groups with nutrient intakes below the EAR. Energy and nutrient intakes did not differ substantially between the two groups except for copper and vitamin C. When adjusted for energy 


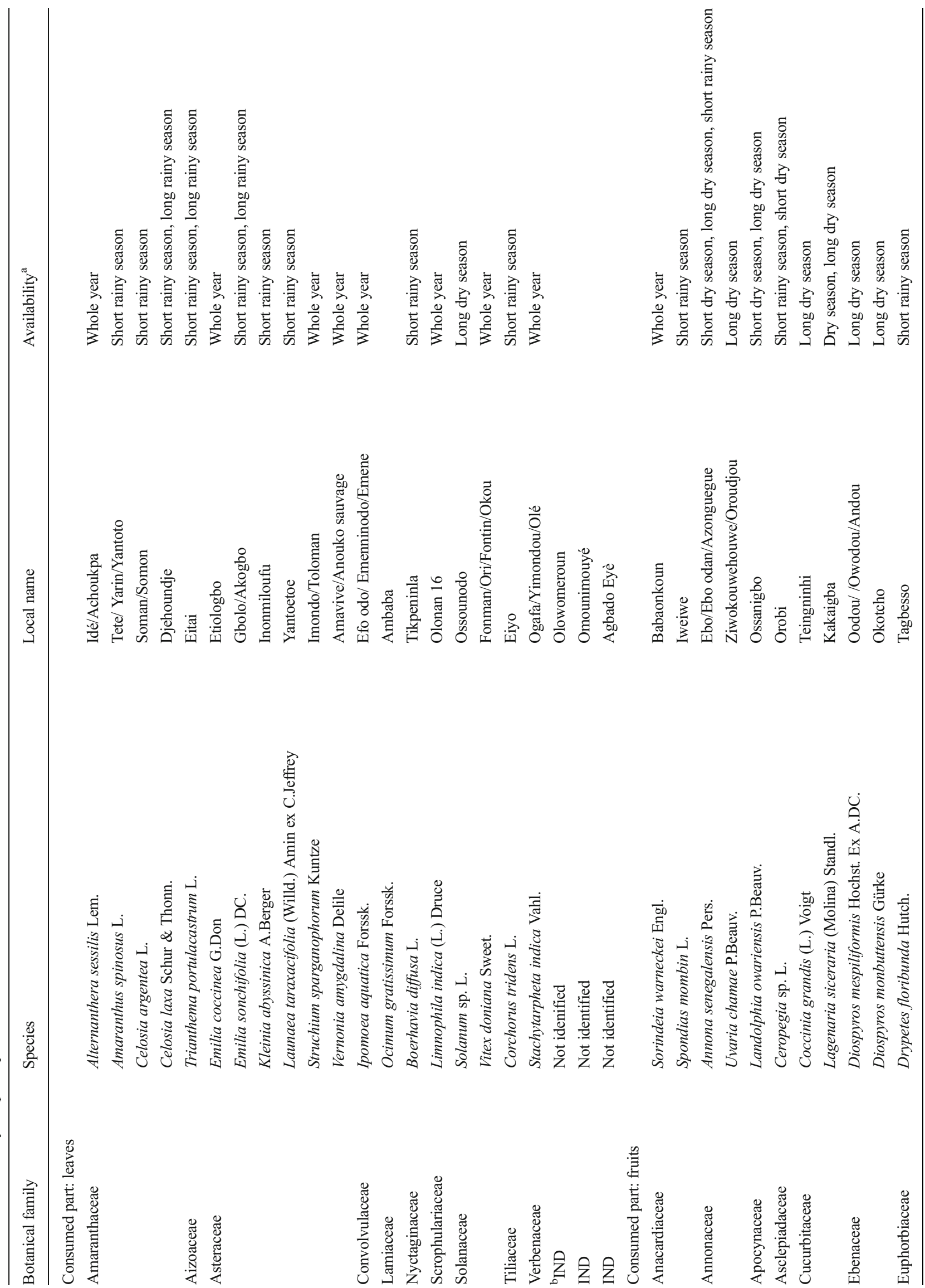




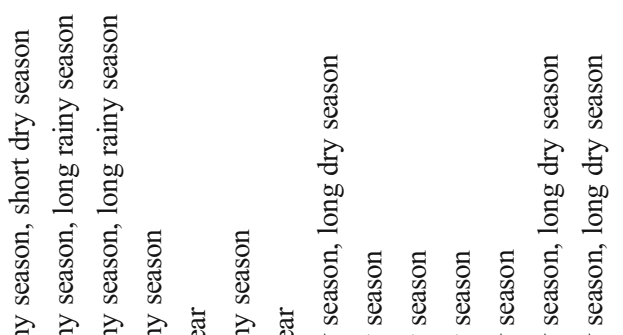

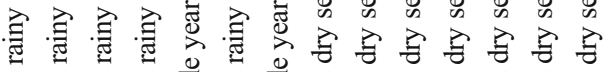

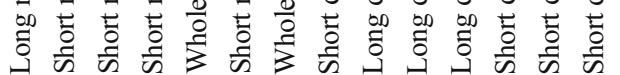

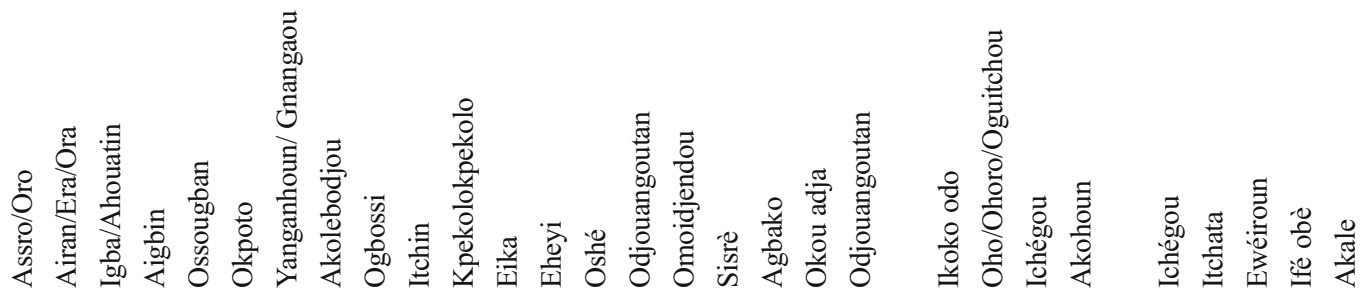

घี่

(2)

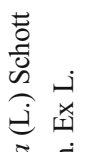

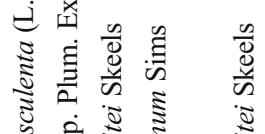

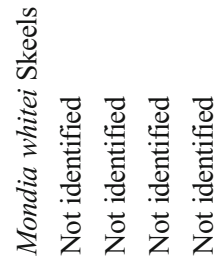

这

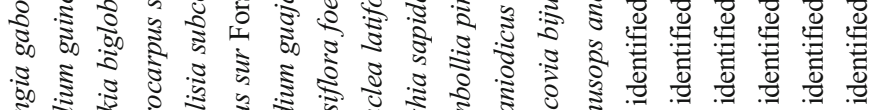

है।

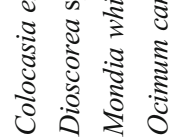

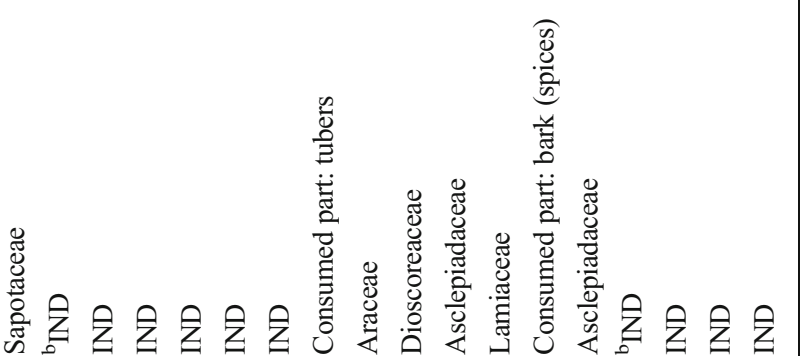

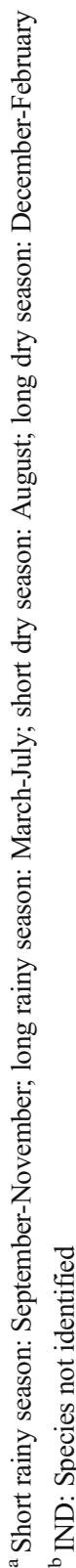


Fig. 1 Number of times a WEP has been cited in the 24-h recalls $(n=220)$. Pa Parkia biglobosa, $S t$ Struchium sparganophorum, $\mathrm{Vi}$ Vitex doniana, Di Dialium guineense, Ip Ipomoea aquatica, Al Alternanthera sessilis, $\mathrm{Ce}$ Celosia argentea var, Am Amaranthus spinosus

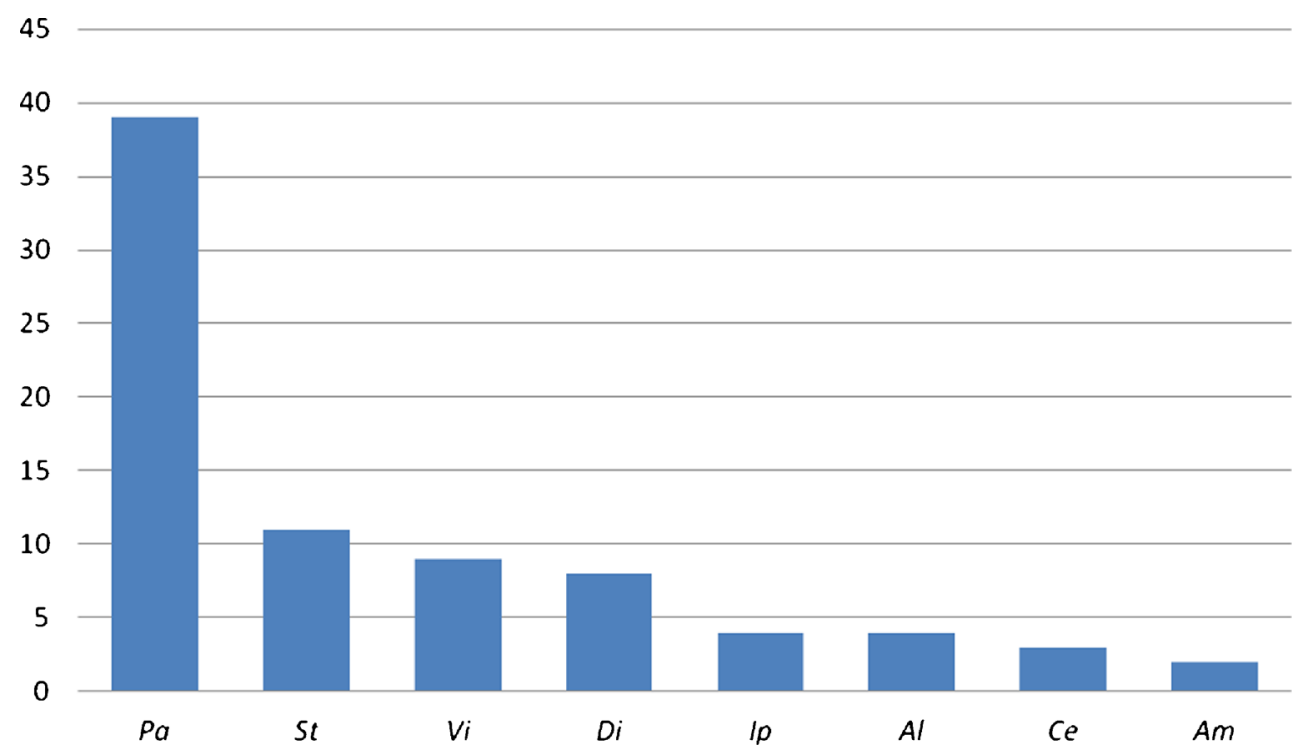

intake (which was higher for WEP consumers than for non consumers), copper intake of WEP consumers was significantly higher than for non consumers. Without adjustment for total energy intake, also vitamin $\mathrm{C}$ intake of WEP consumers would have been significantly higher $(P=0.046)$. For all micronutrients the percentage of non WEP consumers with nutrient intakes below the EAR was higher than the percentage of WEP consumers. Thus, the micronutrient intake of WEP consumers was slightly more adequate than the intake of the non consumers.

WEP knowledge, attitudes, and barriers towards consumption and trade of WEPs

During the structured interviews, more than half of the respondents stated that they regularly consumed wild vegetables (Table 7). Wild fruit and tuber consumption was reported by 38 and $30 \%$, respectively. The interviewed women reported that the vast majority of men in their households consumed WEPs and almost all their children liked them. Wild leafy vegetables play an important role in compensating for food shortages according to $82 \%$ of the respondents and wild fruits and tubers for more than half of the respondents. Figure 2 presents attitudes towards WEPs on 5-point Likert scales. All three WEP categories (leafy vegetables, fruits and tubers) were considered important. In all WEP categories, taste has been the strongest attribute defining this importance, followed by healthiness. Most of the respondents disagreed with the statement that WEPs are part of their cultural identity.

Only $10 \%$ of the women reported availability or accessibility of WEPs all year round. Restrictions on entering the core of the forest were cited as one of the main reasons for unavailability along with seasonality. Most of the respondents reported a decreasing availability of wild vegetables, fruits and tubers over the past $10-20$ years $(74 \%, 87 \%$ and $82 \%$ respectively). For $52 \%$ of the women WEPs were considered affordable. Many respondents reported that WEPs become more expensive in the market during the rainy season and cheaper during the dry season. More than half of the respondents indicated experiencing problems in storing $(60 \%)$ and commercializing ( $73 \%$ ) WEPs, mainly because of their high perishability. Almost half of the women mentioned constraints with regard to preparation and transformation of WEPs (48 \%), mainly prolonged cooking times. About half of the respondents $(53 \%)$ would like to have more information about WEP use, especially about conservation (33\%).

\section{Discussion}

During the long dry season, the contribution of WEPs to total nutrient intakes of adult women living in the buffer zone of the Lama forest in Benin was small and of low dietary significance. However, the nutrients for which WEP percentage contributions were highest (copper and iron), were the nutrients for which a high percentage of women had intakes below the EARs. In addition, WEP consumers have significantly higher copper intakes compared to non WEP consumers. Vitamin C intakes would also be significantly higher for WEP consumers than for non consumers if no adjustment for energy intake was applied. In addition, WEP consumption was significantly related to increased dietary diversity. This indicates that, although WEPs were consumed in too low quantities to significantly contribute to meeting nutrient requirements, consuming WEPs on the day of diet recall was 
Table 3 Proportion of WEP consumers and non WEP consumers consuming food groups/items

\begin{tabular}{|c|c|c|c|}
\hline Food group & $\begin{array}{l}\text { WEP consumers }(n=69) \\
n(\%)\end{array}$ & $\begin{array}{l}\text { Non WEP consumers }(n=45) \\
n(\%)\end{array}$ & $P$ value $^{\mathrm{a}}$ \\
\hline Starchy staples & $69(100.00)$ & $45(100.00)$ & \\
\hline Maize flour & $69(100.00)$ & $45(100.00)$ & \\
\hline Taro & $3(4.35)$ & $2(4.44)$ & 0.658 \\
\hline Yam & $15(21.74)$ & $5(11.11)$ & 0.112 \\
\hline Rice & $21(30.44)$ & $5(11.11)$ & 0.013 \\
\hline Cassava & $13(18.84)$ & $6(13.33)$ & 0.057 \\
\hline Cassava flour & $61(88.41)$ & $39(86.67)$ & 0.500 \\
\hline Bread (wheat) & $3(4.35)$ & $2(4.44)$ & 0.658 \\
\hline Dark green leafy vegetables & $51(73.91)$ & $13(28.89)$ & 0.000 \\
\hline Vernonia amygdalina & $4(5.80)$ & $3(6.67)$ & 0.572 \\
\hline Manihot esculenta & $10(14.49)$ & $3(6.67)$ & 0.163 \\
\hline Solanum macrocarpon & $11(15.94)$ & $7(15.56)$ & 0.587 \\
\hline Corchorus olitorius & $5(7.25)$ & $0(0.00)$ & 0.077 \\
\hline Wild species & $37(53.62)$ & $0(0.00)$ & \\
\hline Celosia argentea & $3(4.35)$ & $0(0.00)$ & \\
\hline Alternanthera sessilis & $4(5.80)$ & $0(0.00)$ & \\
\hline Amaranthus spinosus & $4(5.80)$ & $0(0.00)$ & \\
\hline Struchium sparganophora & $13(18.84)$ & $0(0.00)$ & \\
\hline Ipomoea aquatica & $4(5.80)$ & $0(0.00)$ & \\
\hline Vitex doniana & $10(14.49)$ & $0(0.00)$ & \\
\hline Other vitamin A rich fruits and vegetables & $69(100.00)$ & $45(100.00)$ & \\
\hline Palm oil & $69(100.00)$ & $45(100.00)$ & \\
\hline Chili pepper dried & $69(100.00)$ & $45(100.00)$ & \\
\hline Tomato powder & $4(5.80)$ & $0(0.00)$ & 0.130 \\
\hline Other fruits and vegetables & $69(100.00)$ & $45(100.00)$ & \\
\hline Tomato & $34(49.28)$ & $16(35.56)$ & 0.105 \\
\hline Tomato paste & $24(34.78)$ & $17(37.78)$ & 0.448 \\
\hline Banana & $6(8.70)$ & $5(11.11)$ & 0.452 \\
\hline Onion & $69(100.00)$ & $44(97.78)$ & 0.395 \\
\hline Garlic & $62(89.86)$ & $37(82.22)$ & 0.185 \\
\hline Okra fruit & $25(36.23)$ & $17(37.78)$ & 0.511 \\
\hline Chili pepper & $14(20.29)$ & $5(11.11)$ & 0.152 \\
\hline Wild species & $7(10.14)$ & $0(0.00)$ & 0.026 \\
\hline Dialium guineense & $7(10.14)$ & $0(0.00)$ & \\
\hline Meat and fish & $59(85.51)$ & $36(80.00)$ & 0.301 \\
\hline Meat (beef and chicken) & $3(4.35)$ & $1(2.22)$ & 0.483 \\
\hline Fish smoked & $51(73.91)$ & $31(68.89)$ & 0.354 \\
\hline Fish dried & $24(34.78)$ & $4(8.89)$ & 0.001 \\
\hline Legumes, nuts and seeds & $61(88.41)$ & $39(86.66)$ & 0.500 \\
\hline Soya bean & $45(65.22)$ & $27(59.99)$ & 0.356 \\
\hline Cowpea & $19(27.54)$ & $8(17.78)$ & 0.166 \\
\hline Pois d'Angole & $33(47.83)$ & $16(35.56)$ & 0.136 \\
\hline Groundnuts & $30(43.48)$ & $13(28.89)$ & 0.084 \\
\hline Watermelon seeds & $3(4.35)$ & $3(6.67)$ & 0.445 \\
\hline Wild species & $43(62.32)$ & $0(0.00)$ & \\
\hline Soumbala (Parkia biglobosa seeds) & $43(62.32)$ & $0(0.00)$ & \\
\hline Other foods & $69(100.00)$ & $45(100.00)$ & \\
\hline Black pepper & $44(63.77)$ & $31(68.89)$ & 0.361 \\
\hline
\end{tabular}


Table 3 (continued)

\begin{tabular}{llcl}
\hline Food group & $\begin{array}{l}\text { WEP consumers }(n=69) \\
n(\%)\end{array}$ & $\begin{array}{l}\text { Non WEP consumers }(n=45) \\
n(\%)\end{array}$ \\
\hline Bouillon & $66(95.65)$ & $44(97.78)$ & 0.483 \\
Sugar & $47(68.12)$ & $32(71.11)$ & 0.450 \\
Yeast & $16(23.19)$ & $7(15.56)$ & 0.227 \\
Salt & $66(95.65)$ & $44(97.78)$ & 0.636 \\
Groundnut oil & $15(21.74)$ & $4(8.89)$ & 0.058 \\
\hline
\end{tabular}

Only food items that were consumed by at least $3.5 \%$ of the sample are reported

${ }^{\text {a }}$ Chi-Square Tests were performed for all foods except for wild foods and foods/food groups that were consumed by $100 \%$ of the respondents of both groups

associated with higher dietary diversity and slightly better micronutrient adequacy. The most consumed WEP product was soumbala, which is only used in small quantities as a condiment in several dishes.

Penafiel et al. (2011) in their systematic multidisciplinary review on the contribution of biodiversity to local diets concluded that there is a huge lack of studies combining thorough biodiversity assessments with appropriate dietary assessment methodologies. The studies of Powell et al. (2013), Ogle et al. $(2001 \mathrm{a}-\mathrm{c})$ and Termote et al. (2012) belong to the small number that have assessed the dietary contribution of wild foods using valid dietary assessment methods. Powell et al. (2013), analyzing women's diets in rural Tanzania using 24-h recalls, found higher contributions of wild foods to energy (1.5\%) and nutrient intakes (3.7 to $31.9 \%$ ). However, these contributions cannot be compared with the present results because they included nutrient-rich foods from wild animals in their wild foods. Ogle and co-workers using a simple 7 day food frequency questionnaire (FFQ), found that WEPs made important contributions to the $\beta$-carotene, Vitamin $C$, calcium and iron intakes in the Mekong Delta in Vietnam (Ogle et al. 2001a), that wild vegetables contributed significantly to the overall micronutrient intake (calcium, iron, Vitamin A, thiamine, riboflavin, niacin, Vitamin C) (Ogle et al. 2001b) and that wild vegetable consumption was responsible for $21 \%$ and $14 \%$ of the folate intake of women in the Mekong Delta and the Central Highlands, respectively (Ogle et al. 2001c). Termote et al. (2012) reported rare WEP consumption and small contributions to the dietary intake of rural women in a highly biodiverse region in DR Congo. Comparing the nutrient intake of WEP consumers and non WEP consumers, Termote et al. (2012) found that the consumers had significantly higher intakes of Vitamin A, Vitamin C, Vitamin B6 and calcium (all nutrients adjusted for energy). The present study only found a significant difference for copper (adjustment for energy) and vitamin C intakes (without adjustment for energy) which were higher among WEP consumers.

Table 4 Usual daily food group consumption of WEP consumers and non WEP consumers

\begin{tabular}{lcc}
\hline Food group & $\begin{array}{c}\text { WEP consumers }(n=69) \\
\text { Median }(\mathrm{g}) /\left(\mathrm{P}_{25} \mathrm{P}_{75}\right)^{\mathrm{a}}\end{array}$ & $\begin{array}{l}\text { Non WEP consumers }(n=45) \\
\text { Median }(\mathrm{g}) /\left(\mathrm{P}_{25} \mathrm{P}_{75}\right)^{\mathrm{a}}\end{array}$ \\
\hline Starchy staples & $1,037.22(712.90 ; 1,513.20)$ & $972.10(623.75 ; 1,476.34)$ \\
Dark green leafy vegetables & $0.00(0.00 ; 76.55)$ & $0.00(0.00 ; 0.00)$ \\
$\quad$ Wild species & $0.00(0.00 ; 42.00)$ & $0.00(0.00 ; 0.00)$ \\
Other vitamin A rich fruits and vegetables & $208.00(117.16 ; 386.72)$ & $154.00(73.70 ; 323.04)$ \\
Other fruits and vegetables & $74.10(42.25 ; 18.20)$ & $74.20(30.30 ; 130.20)$ \\
$\quad$ Wild species & $0.00(0.00 ; 0.00)$ & $0.00(0.00 ; 0.00)$ \\
Meat and fish & $12.80(0.00 ; 37.05)$ & $8.60(0.00,40.25)$ \\
Legumes, nuts and seeds & $78.30(13.50 ; 166.10)$ & $57.40(17.00 ; 158.00)$ \\
$\quad$ Wild species & $0.00(0.00 ; 5.90)$ & $0.00(0.00 ; 0.00)$ \\
Other foods & $28.80(9.3 ; 44.90)$ & $20.80(8.9 ; 43.70)$ \\
WDDS & $5.1^{\mathrm{c}}$ & $4.5^{\mathrm{c}}$ \\
\hline
\end{tabular}

a All values are usual median intakes with 25 th and 75th percentile, and adjustment for 'interviewer'

${ }^{\mathrm{b}}$ ANOVA comparison of means

${ }^{\mathrm{c}}$ Potential score range for WDDS: 0-9 
Table 5 Usual daily total dietary intakes; proportion of women with nutrient intakes under EAR, usual daily dietary intakes from WEPs and their contributions to total intake

\begin{tabular}{|c|c|c|c|c|}
\hline Energy/ nutrient & Median intake $\left(\mathrm{P}_{25} ; \mathrm{P}_{75}\right)$ & $\%$ women under EAR & $\begin{array}{l}\text { Median intake } \\
\text { from WEPs }\left(\mathrm{P}_{25} ; \mathrm{P}_{75}\right)\end{array}$ & $\begin{array}{l}\text { WEP contribution to } \\
\text { nutrient intake }(\%)\end{array}$ \\
\hline Energy (kcal) & $4,235.91(3,426.17 ; 5,210.10)$ & & $13.44(7.82 ; 19.83)$ & 0.32 \\
\hline Energy from protein $(\%)$ & $10.10(8.38 ; 12.45)$ & & $1.42(0.84 ; 1.78)$ & 1.33 \\
\hline Energy from fat (\%) & $24.40(18.19 ; 31.31)$ & & $0.59(0.31 ; 1.03)$ & 0.52 \\
\hline Energy from carbohydrates (\%) & $57.01(46.53 ; 67.10)$ & & $0.70(0.43 ; 1.68)$ & 0.12 \\
\hline Fiber $(g)$ & $69.61(57.57 ; 87.14)$ & & $0.52(0.27 ; 0.75)$ & 0.75 \\
\hline Vitamin A ( $\mu \mathrm{g}$ RE) & $4,303.44(2,821.53 ; 5,427.91)$ & 0.00 & $9.68(4.96 ; 42.41)$ & 0.23 \\
\hline Vitamin C (mg) & $48.61(42.20 ; 55.61)$ & 6.14 & $1.13(0.68 ; 5.04)$ & 2.32 \\
\hline Vitamin D ( $\mu g)$ & $92.35(42.17 ; 139.54)$ & 2.63 & $0.00(0.00 ; 0.00)$ & 0.00 \\
\hline Vitamin E (mg) & $23.84(18.40 ; 29.11)$ & 0.00 & $0.10(0.04 ; 0.42)$ & 0.45 \\
\hline Thiamine (mg) & $2.15(1.73 ; 2.75)$ & 0.00 & $0.01(0.00 ; 0.02)$ & 0.47 \\
\hline Riboflavin (mg) & $1.19(0.97 ; 1.55)$ & 19.30 & $0.03(0.02 ; 0.07)$ & 2.52 \\
\hline Niacin (mg) & $13.13(10.73 ; 15.69)$ & 28.95 & $0.21(0.12 ; 0.31)$ & 1.60 \\
\hline Vitamin B6 (mg) & $2.27(1.86 ; 2.80)$ & 1.75 & $0.03(0.01 ; 0.05)$ & 1.32 \\
\hline Folate $(\mu \mathrm{g})$ & $426.58(303.98 ; 539.34)$ & 29.82 & $3.32(1.86 ; 8.98)$ & 0.78 \\
\hline Vitamin B-12 $(\mu \mathrm{g})$ & $0.91(0.55 ; 1.28)$ & 88.60 & $0.00(0.00 ; 0.00)$ & 0.00 \\
\hline Calcium (mg) & $948.62(757.73 ; 1,134.36)$ & 33.33 & $24.18(14.51 ; 63.74)$ & 2.55 \\
\hline Iron (mg) & $41.45(35.19 ; 50.95)$ & 91.23 & $1.91(1.07 ; 3.11)$ & 4.61 \\
\hline Zinc (mg) & $17.58(13.40 ; 22.24)$ & 1.75 & $0.01(0.01 ; 0.02)$ & 0.10 \\
\hline Magnesium (mg) & $814.46(675.46 ; 1,007.03)$ & $0.00^{\mathrm{a}}$ & $8.60(3.48 ; 20.81)$ & 1.10 \\
\hline Potassium (mg) & $4,460.29(3,363.60 ; 5,458.66)$ & No EAR available & $14.91(6.78 ; 57.91)$ & 0.33 \\
\hline Sodium (mg) & $3,152.34(2,235.46 ; 3,935.14)$ & No EAR available & $9.25(5.77 ; 20.33)$ & 0.29 \\
\hline Phosphate (mg) & $1,655.33(1,395.30 ; 2,130.40)$ & $0.00^{\mathrm{a}}$ & $12.17(6.09 ; 17.66)$ & 0.74 \\
\hline Copper (mg) & $6.10(4.56 ; 7.67)$ & $64.91^{\mathrm{a}}$ & $0.85(0.33 ; 3.70)$ & 13.93 \\
\hline
\end{tabular}

All values are usual median intakes with 25th and 75th percentile, and adjustment for 'interviewer'

${ }^{a}$ EAR Canada

Results from this study, and the five papers described above are very divergent. In some cases, WEPs contribute significantly to diets, but in other, at first sight similar contexts (biodiverse regions, considerable knowledge of WEPs and micronutrient inadequacy of diets), they do not contribute significantly to diets. Much more research is needed to disentangle the conditions and factors such as seasonality, socioeconomic, political, cultural and environmental characteristics that determine WEP use, in order to better understand the relationship between nutrition and biodiversity.

Our findings are in line with those of Termote et al. (2012) and furthermore indicate that there is a big gap between the number of locally known and available WEPs that have potential to contribute to local diets, and their actual consumption and contribution to diets. Altogether, the respondents in our study knew 61 WEPs. At the time of survey, which was the long dry season, 16 WEPs were out of harvest season, 32 WEPs were reported to be available for harvest and for 13 WEPs we did not have seasonality information. Out of all known WEPs, only eight were found in $37 \%$ of the two 24-h recalls. It is surprising that WEPs were not consumed more frequently and in larger quantities, given that $90 \%$ of the interviewed women answered positively to the question whether they often collected them (Table 1). Moreover, half the women said they did so for own consumption. In addition, $87 \%$ of the households experienced some form of food insecurity during the long dry season, the period of research (Table 1).

Some of the most frequently cited reasons for the decline in use of traditional food species that have been reported from regions all over the world are: declining availability of wild foods due to overharvesting and land clearance for agriculture; difficulties in access to land and land tenure; local populations' perceptions about wild foods as being 'food for the poor'; loss of traditional knowledge; high work load to collect, process and prepare traditional foods; integration in market economies and globalization (Kuhnlein et al. 2009; Barucha and Pretty 2010). The present study demonstrates that it is unlikely that the low levels of WEP consumption were due to insufficient appreciation of WEPs. They are considered as important during periods of food shortages and deemed to be tasty, healthy and nutritious (Table 7, Fig. 2). Nevertheless, some constraints with regard to WEP consumption and/or 
Table 6 Usual daily dietary intakes of WEP consumers and non WEP consumers and proportion of women under the EAR

\begin{tabular}{|c|c|c|c|c|c|c|}
\hline Energy/nutrient & $\begin{array}{l}\text { WEP consumers }(n=69) \\
\text { Median }\left(\mathrm{P}_{25} ; \mathrm{P}_{75}\right)\end{array}$ & $\begin{array}{l}\text { \% women under } \\
\text { EAR }\end{array}$ & $\begin{array}{l}\text { Non WEP consumers }(n=45) \\
\text { Median }\left(\mathrm{P}_{25} ; \mathrm{P}_{75}\right)\end{array}$ & $\begin{array}{l}\text { \% women under } \\
\text { EAR }\end{array}$ & $\begin{array}{l}\text { Difference } \\
\text { of } \\
\text { medians }\end{array}$ & $\begin{array}{l}P \\
\text { value }^{\mathrm{b}}\end{array}$ \\
\hline Energy $(k c a l)$ & $4,314.58(3,541.91 ; 5,455.98)$ & & $4,192.74(3,265.96 ; 5,150.48)$ & & 121.84 & 0.501 \\
\hline $\begin{array}{l}\text { Energy from } \\
\text { protein }(\%)\end{array}$ & $9.27(7.89 ; 11.83)$ & & $11.53(9.28 ; 12.68)$ & & & \\
\hline $\begin{array}{l}\text { Energy from fat } \\
\qquad(\%)\end{array}$ & $23.10(17.92 ; 30.23)$ & & $25.47(17.33 ; 51.52)$ & & & \\
\hline $\begin{array}{l}\text { Energy from } \\
\text { carbohydrates } \\
(\%)\end{array}$ & $53.90(44.70 ; 63.45)$ & & $59.21(48.10 ; 72.52)$ & & & \\
\hline Fibre $(g)^{\mathrm{c}}$ & $67.80(55.96 ; 80.30)$ & & $74.65(65.50 ; 94.35)$ & & -6.85 & 0.173 \\
\hline $\begin{array}{l}\text { Vitamin } \mathrm{A}(\mu g \\
R E)^{\mathrm{c}}\end{array}$ & $4,377.39(2,944.93 ; 5,659.45)$ & 0.00 & $4,107.60(2,700.72 ; 4,914.77)$ & 0.00 & 269.79 & 0.139 \\
\hline Vitamin $\mathrm{C}(\mathrm{mg})^{\mathrm{c}}$ & $52.39(43.88 ; 62.96)$ & 1.50 & $38.32(35.16 ; 42.34)$ & 22.22 & 14.07 & 0.848 \\
\hline Vitamin D $(\mu g)^{\mathbf{c}}$ & $82.33(33.13 ; 129.53)$ & 2.89 & $103.82(70.93 ; 162.27)$ & 2.22 & -21.49 & 0.222 \\
\hline Vitamin E $(m g)^{\mathrm{c}}$ & $23.88(18.48 ; 28.84)$ & 0.00 & $23.74(18.06 ; 30.43)$ & 0.00 & 0.14 & 0.394 \\
\hline Thiamine $(\mathrm{mg})^{\mathrm{c}}$ & $2.02(1.66 ; 2.59)$ & 0.00 & $2.38(2.01 ; 2.90)$ & 0.00 & -0.36 & 0.260 \\
\hline Riboflavin $(\mathrm{mg})^{\mathrm{c}}$ & $1.24(1.05 ; 1.57)$ & 11.59 & $1.12(0.88 ; 1.53)$ & 26.07 & -1.12 & 0.141 \\
\hline Niacin $(m g)^{\mathrm{c}}$ & $13.45(10.50 ; 15.51)$ & 33.33 & $13.35(11.17 ; 15.91)$ & 19.57 & 0.10 & 0.795 \\
\hline Vitamin B-6 $(m g)^{\mathrm{c}}$ & $2.14(1.75 ; 2.74)$ & 0.00 & $2.40(1.96 ; 2.84)$ & 4.40 & -0.26 & 0.270 \\
\hline Folate $(\mu g)^{\mathrm{c}}$ & $428.90(325.39 ; 517.75)$ & 24.64 & $414.50(268.75 ; 613.57)$ & 33.33 & 14.40 & 0.496 \\
\hline Vitamin B-12 $(\mu g)^{\mathrm{c}}$ & $0.90(0.56 ; 1.16)$ & 88.41 & $0.93(0.57 ; 1.36)$ & 88.88 & -0.03 & 0.703 \\
\hline Calcium $(\mathrm{mg})^{\mathrm{c}}$ & $941.27(767.03 ; 1,141.76)$ & 30.43 & $930.80(752.33 ; 1,184.95)$ & 35.55 & 10.47 & 0.775 \\
\hline Magnesium $(m g)^{\mathrm{c}}$ & 763.97 (637.69; 928.49) & $0.00^{\mathrm{a}}$ & $902.25(729.12 ; 1,083.60)$ & 0.00 & -138.98 & 0.897 \\
\hline Phosphate $(m g)^{\mathrm{c}}$ & $1,579.78(1,356.95 ; 2,033.46)$ & $0.00^{\mathrm{a}}$ & $1,833.79(1,511.60 ; 2,190.80)$ & 0.00 & -259.01 & 0.542 \\
\hline Potassium $(m g)^{\mathrm{c}}$ & $4,329.22(3,484.21 ; 5,237.57)$ & No EAR available & $4,763.56(3,315.73 ; 5,723.10)$ & No EAR available & -434.34 & 0.664 \\
\hline Sodium $(m g)^{\mathrm{c}}$ & $3,224.24(2,336.16 ; 3,761.16)$ & No EAR available & $3,092.16(2,109.64 ; 4,453.79)$ & No EAR available & 132.08 & 0.743 \\
\hline $\operatorname{Iron}(m g)^{\mathrm{c}}$ & $40.09(35.35 ; 50.34)$ & 91.30 & $45.32(34.96 ; 50.97)$ & 88.89 & -5.23 & 0.498 \\
\hline $\operatorname{Zinc}(m g)^{\mathrm{c}}$ & $16.09(13.38 ; 20.91)$ & 1.45 & $20.45(13.75 ; 23.39)$ & 2.22 & -4.36 & 0.349 \\
\hline Copper $(m g)^{\mathrm{c}}$ & $7.80(6.02 ; 11.51)$ & $35.71^{\mathrm{a}}$ & $3.88(2.74 ; 5.02)$ & 95.65 & 3.92 & 0.008 \\
\hline
\end{tabular}

All values are usual median intakes with 25th and 75th percentile and adjustment for 'interviewer'

${ }^{a}$ EAR Canada

${ }^{\mathrm{b}}$ ANOVA comparison of means

${ }^{\mathrm{c}} P$ adjusted for total energy intake in the model as described by Willett $(1,998)$

commercialization were documented, particularly regarding perishability, storage, commercialization, availability (seasonality) and accessibility (restrictions on entering the core of the forest), but also extra burdens on time use were mentioned as WEPs need longer cooking times according to our respondents. Low WEP consumption despite encouraging circumstances does not seem to be uncommon. Termote et al. (2012) found 11 WEPs in approximately 1,000 24-h recalls out of a total of 77 WEPs known in a rural village in DRC. A study conducted in a rural community in Cameroon reported 24 WEPs were used as sources of food but only a few were used frequently (Hamawa 2013). A study conducted in rural South Africa also found that not all available wild vegetables were necessarily consumed, due to certain constraints, and if they were consumed the quantities were small (Mavengahama et al. 2013). In a rural area of Ethiopia the state of wild fruit utilization has been very low as well due to food habits, cultural perception and attitudes (Fentahun and Hager 2009).

Different authors have stated that consuming WEPs often belongs to the intangible cultural heritage of local populations (Pieroni 2008) and some even say it is a way of expressing cultural identity (Dansi et al. 2008, Pieroni et al. 2005). Although attitudes towards WEPs in this study in general seemed to be positive, most respondents answered negatively to the question of whether WEPs were a part of their cultural identity. Further qualitative research using focus group discussions and/or observations is necessary to obtain more indepth information and better understanding of this result.

As presented in Tables 3 and 4, WEP consumers and non consumers have a very similar diet. WEPs complement the diet rather than being a substitute for other food species. This contrasts with the findings of Mavengahama et al. (2013) who 
Table 7 WEP consumption

\begin{tabular}{ll}
\hline & $(n=120) n(\%)$ \\
\hline Subjects consuming WEPs regularly & \\
$\quad$ Vegetables & $80(66.7)$ \\
Fruits & $46(38.3)$ \\
Tubers & $36(30)$ \\
Subjects whose male household & \\
members consume WEPs & \\
Vegetables & $119(92.2)$ \\
Fruits & $113(94.2)$ \\
Tubers & $107(89.2)$ \\
Subjects whose children like & \\
consuming WEPs & \\
$\quad$ Vegetables & $120(100)$ \\
Fruits & $119(99.2)$ \\
Tubers & $110(91.7)$ \\
\hline
\end{tabular}

reported that wild vegetables are consumed when meat and exotic vegetables cannot be afforded in rural South Africa. With regard to dietary diversity, WEP consumers and non WEP consumers reported averages of 5.1 and 4.5 food groups out of 9, respectively. Keding et al. (2012) found that about one third of rural women in Tanzania had a monotonous diet with a very low Dietary Diversity Score of only 2-4 out of 14 food groups (mainly cereals, vegetables, oil or fat). As in the present study, fruit consumption was very low. In rural Burkina Faso women had low Dietary Diversity scores as well with only 2-3 food groups (mainly cereals, green leafy vegetables and condiments) (Savy et al. 2005).

Despite the fact that WEPs were not often consumed, we were able to document the presence of some interesting species that are known by the population and that could contribute to better meeting their micronutrient requirements, especially copper, iron, Vitamin $\mathrm{C}$, riboflavin, calcium and folate. For these, quite a number of women had intakes below the EAR values (Tables 5 and 6). WEPs would not, however, be able to improve the critical Vitamin B-12 intake, as this vitamin is mainly available in foods from animal sources (FAO/WHO 2004). Good examples of WEPs that could contribute to an improved intake of critical nutrients if consumed more often or in larger quantities include the wild leafy vegetable, Vitex doniana, ${ }^{2}$ that shows high values in riboflavin $(0.53 \mathrm{mg} / 100 \mathrm{~g})$, folate $(105 \mathrm{mg} / 100 \mathrm{~g})$, Vitamin C $(80 \mathrm{mg} / 100 \mathrm{~g})$ and copper $(63 \mathrm{mg} / 100 \mathrm{~g})$. The wild leafy vegetable, Celosia argentea, is rich in these nutrients as well. Soumbala ${ }^{3}$ and the leaves of Struchium sparganophorum ${ }^{4}$ are very rich in

\footnotetext{
$\overline{{ }^{2} \text { Mean portion }}$ size as calculated from this study $=46 \mathrm{~g}$, this means $0.17 \mathrm{mg}$ riboflavin, $26.05 \mu \mathrm{g}$ folate, $15.87 \mathrm{mg}$ Vitamin $\mathrm{C}$ and $30.65 \mathrm{mg}$ copper per average portion size in this study

${ }^{3}$ Mean portion size as calculated from this study $=7 \mathrm{~g}$, this means $4.87 \mathrm{mg}$ iron and $29.12 \mathrm{mg}$ calcium per average portion size

${ }^{4}$ Mean portion size as calculated from this study $=101.8 \mathrm{~g}$, this means $14.35 \mathrm{mg}$ iron per average portion size
}

iron $(69.6 \mathrm{mg} / 100 \mathrm{~g}$ and $18.8 \mathrm{mg} / 100 \mathrm{~g}$ respectively). Soumbala also contains high amounts of calcium (416 mg/100 g). This indicates that, although WEPs are currently consumed in too small amounts to significantly contribute to meeting requirements, they have potential to improve dietary diversity and micronutrient intake if they can be sourced sustainably.

Providing more information on WEP use and promotion of WEP consumption as part of a development program to improve nutrition as well as cultural well-being, has also been proposed by Mahapatra and Panda (2012), Nesamvuni et al. (2001) and Mavengahama et al. (2013). To be confident about the nutritional potential of WEPs, additional research concerning nutrient gaps in target groups, and nutrient composition and bioavailability of nutrients of WEPs is necessary. An assessment about the economic value of WEPs in the Lama region would also be helpful. Frison et al. (2006) confirms that if WEPs could be utilized to increase dietary diversity and food security, sound empirical information on those plants needs to be available. Furthermore, farmers' preferences need to be taken into account. To promote WEP consumption sustainably and avoid WEP depletion, sustainable harvest levels should be determined and respected. Several studies also suggest investigating the potential for integration of WEPs into smallholder cropping systems and home gardens to increase their availability (Mavengahama et al. 2013; Termote et al. 2011), especially when WEPs are starting to be commercialized.

The performance of two 24-h recalls on non-consecutive days is a strength of this study as it allows correction for intraindividual variance. Individual recipes for each of the respondents could be documented in almost all cases as most of the women prepared their meals at home. Extreme intakes were not excluded from the dataset because they belong to the dietary habits in the sample as observed during fieldwork by the first author. The very high median energy intake of 4,315 kcal is remarkable and mainly comes from high intakes of maize flour and palm oil. Despite the high level of physical activity reported by the respondents, some over reporting from the respondents cannot be excluded. However, similar high energy intakes have been published before by Mennen et al. (2000) who investigated the habitual diet of rural Cameroonian women $(3,896 \mathrm{kcal} /$ day). A photo book could have helped the women to better estimate portion sizes, though, as common in many parts of Africa, most women eat from a common pot, which makes estimates of portion size difficult even with a photo book (Huybregts et al. 2008). Notwithstanding these high energy intakes, most of the women did not meet multiple EARs for micronutrient intakes, which would have even been worse in the case of lower energy intake.

Another difficulty faced was the fact that a national FCT for Benin is lacking. Therefore the West African FCT (Stadlmayr et al. 2011) was used and complemented with data from other tables. When consumed food items or certain nutrient values could not be found in any of the tables, data from similar foods 

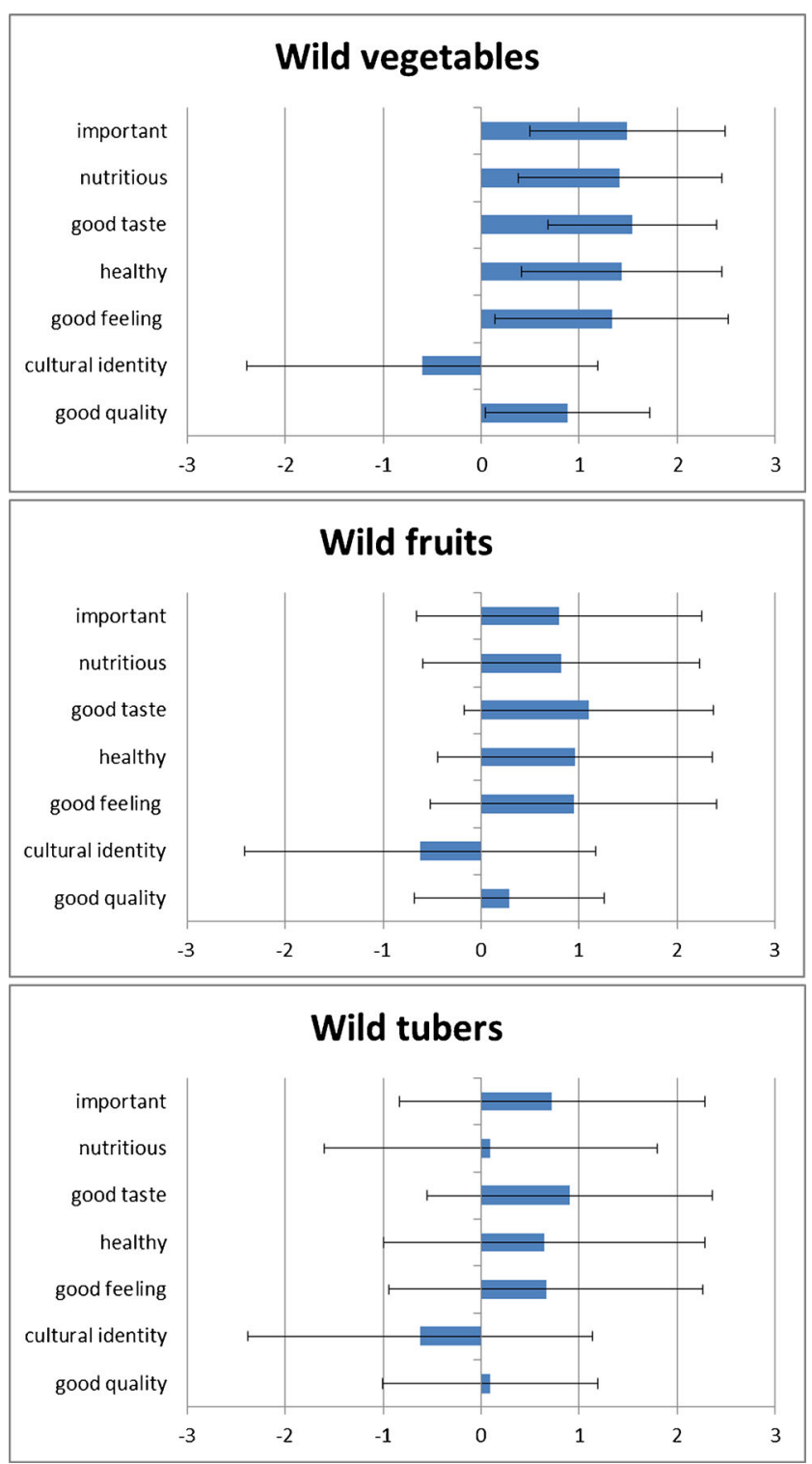

Fig. 2 Attitudes towards WEPs on a 5-point Likert scale

were used. Unfortunately, there is still very little nutrient information available for WEPs, though for more than half of the WEPs consumed, nutrient values could be found in the literature. More research into food composition of local foods is urgently needed.

Finally, our research was carried out at the end of the dry season, which corresponds to the most food insecure period of the year. To increase the significance of the results, the same research could be repeated during the rainy season as the WEP availability and WEP prices change according to season.

\section{Conclusion}

During the dry season period of food insecurity, WEPs do not contribute significantly to the diets of non-pregnant and non- lactating rural women living in the buffer zone of the Lama forest in Southern Benin. However, WEPs appear to supplement the diets and, if consumed more often and in larger quantities, they have the potential to improve dietary diversity and nutrient adequacy. Promoting increased use of available biodiversity to improve dietary intake whether or not combined with income generation through WEP commercialization and/or participatory domestication of priority WEPs, may be possible strategies to increase food and nutrition security in the region of the Lama forest.

Only a few studies have investigated the actual dietary contributions of WEPs. Their results seem to be quite divergent according to context and region, but they all agree upon the huge (often untapped) potential of biodiversity to support sustainable food systems. It is necessary to further build the evidence base on the actual and potential contributions of WEPs and to perform more studies on their nutrient profiles, resilience, use and popularity.

Acknowledgments We thank all the women of the Lama forest who participated in this study for their kindness, trust and patience. Special thanks go to the agronomy students Wassilatou Ibrahima Abdou and Florent Noulekoun from the University Abomey-Calavi and the field guide Radji Mondjo for their great cooperation. The first author obtained a grant from the Flemish Interuniversity Council (Vlir) for performing the fieldwork while a student at Ghent University (Belgium). Analysis and writing were partly funded through an internship at Bioversity International and the Agriculture for Nutrition and Health (A4NH) CGIAR research programme.

Conflict of interest The authors declare that they have no conflict of interest.

Open Access This article is distributed under the terms of the Creative Commons Attribution License which permits any use, distribution, and reproduction in any medium, provided the original author(s) and the source are credited.

\section{References}

Achigan-Dako, E. G., N'Danikou, S., Assogba-Komlan, F., AmbroseOji, B., Ahanchede, A., \& Pasquini, M. W. (2011). Diversity, Geographical, and Consumption patterns of traditional vegetables in sociolinguistic communities in Benin: implications for domestication and utilization. Economic Botany, 65(2), 129-145.

Achigan-Dako, E. G., Pasquini, M. W., Assogba Komlan, F., N'Danikou, S., Dansi, A., \& Ambrose-Oji, B. (2010). Traditional vegetables in Benin. Institut National des Recherches Agricoles du Bénin. Cotonou: Imprimeries du CENAP.

Agea, J. G., Obua, J., Kaboggoza, J. R. S., \& Waiswa, D. (2007). Diversity of indigenous fruit trees in the traditional cotton-millet farming system: the case of Adwari subcounty, Lira District, Uganda. African Journal of Ecology, 45, 39-43.

Akinnifesi, F. K., Jordaan, D., Ham, C. (2005). Building opportunities for smallholder farmers to commoditize indigenous fruit trees and products in southern Africa: processing, markets and rural livelihoods. Book of abstracts. In E. Tielkes, C. Hülsebusch, I. Häuser et al. (Eds.). The global food and product chain-dynamics, innovation, 
conflicts, strategies. University of Hohenheim, Deutscher Tropentag, Stuttgart-Hohenheim.

Akoègninou, A., van der Burg, W. J., van der Maesen, L. J. G., Adjakidjè, V., Essou, J. P., \& Sinsin, B. (2006). Flore du Bénin. Leiden: Blackhuys Publishers.

Arimond, M., Wiesmann, D., Becquey, E., Carriquiry, A., Daniels, M. C., Deitchler, M., Fanou-Fogny, N., Joseph, M. L., Kennedy, G., MartinPrevel, Y., \& Torheim, L. E. (2010). Simple food group diversity indicators predict micronutrient adequacy of Women's diets in 5 diverse, resource-poor settings. The Journal of Nutrition, 140(11), 2059-2069.

Asif, M. \& Kamran, A. (2013). J.M. Lenné \& D. Wood (eds.): Agrobiodiversity management for food security: A critical review. Food Security, 5, 139-140.

Barikmo, I., Ouattara, F., Oshaug, A. (2004). Table de composition d'aliments du Mali Food Composition Table for Mali Research series No. 9. Akershus University College, Norway.

Barucha, Z., \& Pretty, J. (2010). The roles of wild foods in agricultural systems. Philosophical Transactions of the Royal Society B, 365, 2913-2926.

Bradford, K. J. \& Harada, J. J. (2010). Special Issue: Translational Seed Biology: From Model Systems to Crop Improvement. Plant Science 179, 553-553.

Chennai Platform for Action. (2005). Agricultural biodiversity and elimination of hunger and poverty: UN millennium development goals 5 years later. Retrieved 2006-04-12: www.ipgri.cgiar.org/Events/ IFAD-NUS/PDF/Agreement5.pdf Accessed 25/11/2012.

Dansi, A., Adjatin, A., Adoukonou-Sagbadja, H., Falade, V., Yedomonhan, H., Odou, D., \& Dossou, B. (2008). Traditional leafy vegetables and their use in the Benin Republic. Genetic Resources and Crop Evolution, 55, 1239-1256.

Djego, D. S. (2003). Détermination de l'aire de répartition de la population de colobe magistrat (Colobus vellerosus) et statuts de conservation au bénin. Mémoire de DESS/FSA. AbomeyCalavi, Bénin.

EFCOVAL (2010). Multiple Source Method (MSM) for estimation usual dietary intake from short-term measurement data. Potsdam, EFCOVAL work package WP3. http://nugo.drive.de/msm Accessed 25/10/2013

FAO (2005). Building on gender, agrobiodiversity and local knowledge. A training manual. Rome, Food and Agriculture Organization of the United Nations.

FAO (2010). Guidelines for Measuring Household and Individual Dietary Diversity. Rome, Food and Agriculture Organization of the United Nations.

FAO (2013a). Linkages between biodiversity, food and nutrition. Commission on Genetic Resources for Food and Agriculture. Fourteenth Regular Session. Rome, Food and Agriculture Organization of the United Nations. http://www.fao.org/docrep/ meeting/027/mf561e.pdf Accessed 25/10/2013.

FAO (2013b). Narrowing the Nutrient Gap: Investigating in Agriculture to Improve Dietary Diversity. Rome, Food and Agriculture Organization of the United Nations.

FAO/WHO (2004). Vitamin and mineral requirements in human nutrition. Rome, Food and Agriculture Organization of the United Nations. Geneva, World Health Organization.

Fentahun, M. T., \& Hager, H. (2009). Exploiting locally available resources for food and nutritional security enhancement: wild fruits diversity, potential and state of exploitation in the Amhara region of Ethiopia. Food Security, 1, 207-219.

Figueroa, B. M., Tittonell, P., Giller, K. E., Ohiokpehai, O. (2009). The contribution of traditional vegetables to household food security in two communities of Vihiga and Migori Districts, Kenya. Proc. IS on Underutilized Plants Acta Horticulturae (ISHS) 806.

Flyman, M. V., \& Afolayan, A. J. (2006). The suitability of wild vegetables for alleviating human dietary deficiencies. South African Journal of Botany, 72(4), 492-497.
Frison, A. E., Smith, I. F., Johns, T., Cherfas, J., \& Eyzaguirre, P. B. (2006). Agricultural biodiversity, nutrition, and health: making a difference to hunger and nutrition in the developing world. Food and Nutrition Bulletin, 27(2), 167-179.

Frison, E. A., Cherfas, J., \& Hodgkin, T. (2011). Agricultural biodiversity is essential for a sustainable improvement in food and nutrition security. Sustainability, 3, 238-253.

Gibson, R. S., \& Ferguson, E. L. (2008). An interactive 24-hour recall for assessing the adequacy of iron and zinc intakes in developing countries. Washington: ILSI-press.

Grivetti, L. E., \& Ogle, B. M. (2000). Value of traditional foods in meeting macro- and micronutrient needs. The wild plant connection. Nutrition Research Reviews, 13, 31-46.

Guinand, Y. and Dechassa, L. (2000). Underdeveloped, drought prone, food insecure: reflections on the role of 'famine foods' at the time of drought. Addis Ababa, United Nations Emergencies Unit for Ethiopia (UNEUE).

Hamawa, Y. (2013). Wild edible plants used by Guiziga people of far north region of Cameroon. International Journal of Medicinal and Aromatic Plants, 3(2), 136-143.

Haubrock, J., Nöthlings, U., Volatier, J.-L., Dekkers, A., Ocké, M., Harttig, U., Illner, A.-K., Knüppel, S., Andersen, L. F., \& Boeing, H. (2011). Estimating usual food intake distributions by using the multiple source method in the EPIC-Potsdam Calibration study. Journal of Nutrition, 141(5), 914-920.

Health Canada (2011). Dietary reference intake tables. http://www.hc-sc.gc. $\mathrm{ca} /$ fn-an/nutrition/reference/table/index-eng.php Accessed 10/10/2013.

Heywood, V. (1999). Use and potential of wild plants in farm households. FAO Farm Systems Management Series 15, Rome.

Huybregts, L., Roberfroid, D., Lachat, C., Van Camp, J., \& Kolsteren, P. (2008). Validity of photographs for food portion estimation in a rural West African setting. Public Health Nutrition, 11(06), 581-587.

Jonnalagadda, S. S., Mitchell, D. C., Smiciklas-Wright, H., Meaker, K. B., Van Heel, N., Karmally, W., \& Kris-Etherton, P. M. (2000). Accuracy of energy intake data estimated by a multiple pass $24 \mathrm{~h}$ dietary recall technique. Journal of the American Dietetic Association, 100, 303-308.

Kebu, B., \& Fassil, K. (2006). Ethnobotanical study of wild edible plants in Derashe and Kucha Districts, South Ethiopia. Journal of Ethnobiology and Ethnomedicine, 2, 53.

Keding, G., Msuya, J. M., Maas, B. L., \& Krawinkel, M. B. (2012). Relating dietary diversity and food variety scores to vegetable production and socio-economic status of women in rural Tanzania. Food Security, 4, 129-140.

Keller, G. B., Mndiga, H., \& Maass, B. (2006). Diversity and genetic erosion of traditional vegetables in Tanzania from the farmer's point of view. Plant Genetic Resources, 3, 400-413.

Kuhnlein, H., Erasmus, B., Spigelski, D., Burlingame, B. (2009). Indigenous Peoples 'food systems and well-being. Rome, Food and Agriculture Organization of the United Nations.

Legwaila, G. M., Mojeremane, W., Madisa, M. E., Mmolotsi, R. M., \& Rampart, M. (2011). Potential of traditional food plants in rural household food security in Botswana. Journal of Horticulture and Forestry, 3(36), 171-177.

Leung, W.-T. W., Busson, F., \& Jardin, C. (1968). Food composition table for use in Africa. Rome: FAO.

Lockett, C. T., Calvert, C. C., \& Grivetti, L. E. (2000). Energy and micronutrient composition of dietary and medicinal wild plants consumed during drought. Study of rural Fulani,Northeastern Nigeria. International Journal of Food Sciences and Nutrition, 51, 195-208.

Mahapatra, A. K., \& Panda, P. C. (2012). Wild edible fruit diversity and its significance in the livelihood of indigenous tribals: evidence from eastern India. Food Security, 4, 219-234.

Mavengahama, S., McLachan, M., \& de Clercq, W. (2013). The role of wild vegetable species in household food security in maize based subsistence cropping systems. Food Security, 5, 227-233. 
Mennen, L. I., Mbanya, J. C., Cade, J., Balkau, B., Sharma, S., Chungong, S., \& Cruickshank, J. K. (2000). The habitual diet in rural and urban Cameroon. European Journal of Clinical Nutrition, $54,150-154$.

Moore, C. \& Raymond, R. D. (2006). Back by Popular Demand: The Benefits of Traditional Vegetables. Rome, International Plant Genetic Resources Institute, p.60.

N'Danikou, S. 2009. Diversity, management and conservation of wild edible plants in the Fon community of Agbohoutogon, South Benin. M.Sc. dissertation, School of the Environment, Natural Resources, Bangor University, Gwynedd, Wales, United Kingdom.

N'Danikou, S., Achigan-Dako, E. G., \& Wong, J. L. G. (2011). Eliciting local values of wild edible plants in Southern Benin to identify priority species for conservation. Economic Botany, 6(4), 381-395.

Nagel, P., Sinsin, B., \& Peveling, R. (2004). Conservation of biodiversity in a relic forest in Benin - an overview. Regio Basiliensis, 45(2), $125-137$.

Nesamvuni, C., Steyn, N. P., \& Potgieter, M. J. (2001). Nutritional value of wild, leafy vegetables consumed by the VhaVhenda. South African Journal of Science, 97, 51-54.

Nordeide, M. B., Hatløy, A., Følling, M., Lied, E., \& Oshaug, A. (1996). Nutrient composition and nutritional importance of green leaves and wild food resources in an agricultural district, Koutiala, in southern Mali. International Journal of Food Science and Nutrition, 47(6), 455-468.

Oboh, G. (2006). Nutritive value, antioxidant and antimicrobial properties of Struchium sparganophora leaves. Journal of Medicinal Food, 9(2), 276-280

Odhav, B., Beerkrum, S., Akula, Us., Baijnath, H. (2007). Preliminary assessment of nutritional value of traditional leafy vegetables in KwaZulu-Natal, South Africa. Journal of Food Composition and Analysis, 20(5), 430-435

Ogle, B. M., Dung, N. N. X., Do, T. T., \& Hambraeus, L. (2001a). The contribution of wild vegetables to micronutrient intakes of women in Vietnam: an example from the Mekong Delta, Vietnam. Ecology of Food and Nutrition, 40, 159-184.

Ogle, B. M., Hung, P., \& Tuyet, H. (2001b). Significance of wild vegetables in micronutrient intakes of women in Vietnam: an analysis of food variety. Asia Pacific Journal of Clinical Nutrition, 10(1), 21-30.

Ogle, B. M., Johannson, M., Tuyet, H. T., \& Johannesson, L. (2001c). Evaluation of the significance of dietary folate from wild vegetables in Vietnam. Asia Pacific Journal of Clinical Nutrition, 27(10), 216221

Oladejo, T. A. (2009). Proximate composition and micronutrient potentials of three locally available wild fruits in Nigeria. African Journal of Agricultural Research, 4(9), 887-892.

Penafiel, D., Lachat, C., Espinel, R., Van Damme, P., \& Kolsteren, P. (2011). Systematic review on the contributions of edible plant and animal biodiversity to human diets. EcoHealth, 8(3), 381-399.

Pieroni, A. (2008). Local plant resources in the ethnobotany of Theth, a village in the Northern lbanian Alps. Genetic Resoures and Crop Evolution, 55, 197-1214.

Pieroni, A., Nebel, S., Santoro, R. F., \& Heinrich, M. (2005). Food for two seasons: culinary uses of non-cultivated local vegetables and mushrooms in a south Italian village. International Journal of Food Sciences and Nutrition, 56, 245-272.

Powell, B., Maundu, P., Kuhnlein, H., \& Johns, T. (2013). Wild foods from farm and forest in the East Usambara Mountains, Tanzania. Ecology of Food and Nutrition, 52, 451-478.

Savy, M., Martin-Prevel, Y., Traissac, P., \& Delpeuch, F. (2005). Use of variety/diversity scores for diet quality measurement: relation with nutritional status of women in a rural area in Burkina Faso. European Journal of Clinical Nutrition, 59(5), 703-716.
Shackleton, C. M. (2003). The prevalence of use and value of wild edible herbs in South Africa. South African Journal of Science, 99, 23-25.

Shackleton, C., \& Shackleton, S. (2004). The importance of Non-timber Forest Products in rural livelihood security and as safety nets: a review of evidence from South-Africa. South African Journal of Science, 100, 658-664.

Sodjinou, R., Agueh, V., Fayomi, B., \& Delisle, H. (2009). Dietary patterns of urban adults in Benin: relationship with overall diet quality and socio-demographic characteristics. European Journal of Clinical Nutrition, 63(2), 222-228. doi:10.1038/sj.ejcn.1602906.

Stadlmayr, B., Enujiugha, N. V., Bayili, G. R., Fagbohoun, G. E., Samb, B., Addy, P., Barikmo, I., Ouattara, F., Oshaug, A., Akinyele, I., Annor, G. A., Bomfeh, K., Ene-Obong, H., Burlingame, B., Smith, I. F., Thiam, I., \& Charrondiere, U. R. (2012). West African food composition table. Rome, Food and Agriculture Organization of the United Nations

Steyn, N. P., Oliver, J., Winter, P., Burger, S., \& Nesamvuni, C. (2001). A survey of wild, green leafy vegetables and their potential in combating micronutrient deficiencies in rural populations. South African Journal of Sciences, 97, 267-378.

Termote, C., Van Damme, P., \& Dhed'a Djailo, B. (2011). Eating from the wild: Turumbu, Mbole and Bali traditional knowledge on non-cultivated edible plants, District Tchopo, DRCongo. Genetic Resources and Crop Evolution, 58, 585618.

Termote, C., Bwama Meyi, M., Dhed'a Djailo, B., Huybregts, L., Lachat, C., Kolsteren, K., \& Van Damme, P. (2012). A biodiverse rich environment does not contribute to a better diet: a case study from DR Congo. PLoS ONE, 7(1), e30533.

Tilman, D., Reich, P. B., \& Knops, J. M. H. (2006). Biodiversity and ecosystem stability in a decade-long grassland experiment. Nature, 441, 629-632.

Ulmar, K. J., Hassan, L. G., Dangoggo, S. M., \& Ladan, M. D. (2007). Nutritional Composition of Water Spinach (Ipomoea aquatica Forsk.) Leaves. Journal of Applied Sciences, 7(6), $803-809$.

UNICEF (2010). Rapid Assessment Sampling in Emergency Situations. New York: USA. http://www.unicef.org/eapro/Rapid_assessment sampling booklet.pdf Accessed 8/7/2014.

USDA Agricultural research service (2007). Table of nutrient retention factors, release 6.Washington D.C.: USDA. http:// www.ars.usda.gov/Services/docs.htm?docid $=9448$ Accessed 29/7/2012.

Venter, S. L., Jansen van Rensburg, W. S., Vorster, H. J., van den Heever, E., \& van Zijl, J. J. B. (2007). Promotion of African leafy vegetables within the agricultural research council vegetable and ornamental plant institute: the impact of the project. African Journal of Food Agriculture Nutrition and Development, 7(4), 1-7.

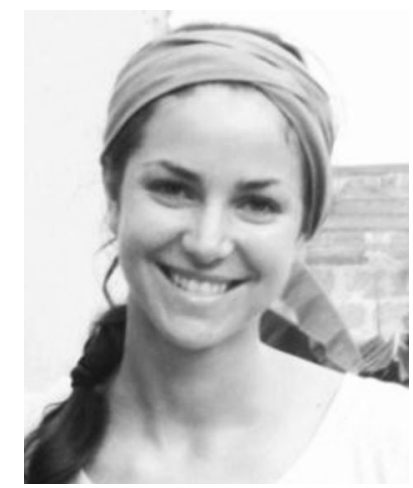

Julia Boedecker a German citizen, obtained a Master's degree in Nutrition and Rural Development at Ghent University in 2013. Her Master's thesis represents the basis for the present paper. During and after her studies she gained working experience at the UNSCN in Geneva, GIZ in Bonn and Bioversity International in Rome. Currently she is working in a project of the German NGO Welthungerhilfe in Liberia. 


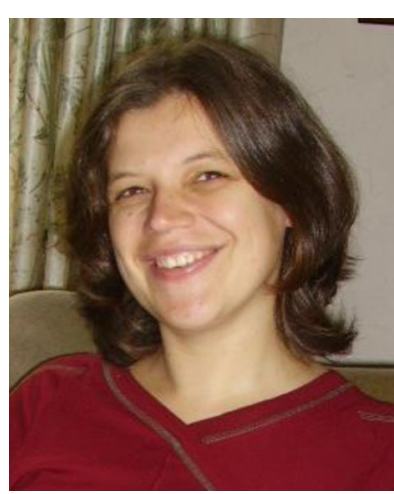

Termote, Céline a Belgian citizen, joined the nutrition and marketing diversity Programme at Bioversity International in January 2013. After obtaining her Master's degree in Applied Biological Sciences, she started her career as development worker for a Belgian NGO. Based in Kabinda, KasaïOriental, DRCongo, she worked with two local partner organizations on food security, sustainable agricultural practices, capacity building and organization strengthening. In late 2005, she rejoined Ghent University as an assistant at the Laboratory of Tropical and Subtropical Agronomy and Ethnobotany and started her multidisciplinary $\mathrm{PhD}$ project on the use of wild edible plants in Tshopo District (Kisangani region), DRCongo. Through joining Bioversity International, she hopes to share and broaden her experiences within the fields of food and nutrition security, sustainable diets, nutrition-sensitive value chains, agroecology and ethnobotany.

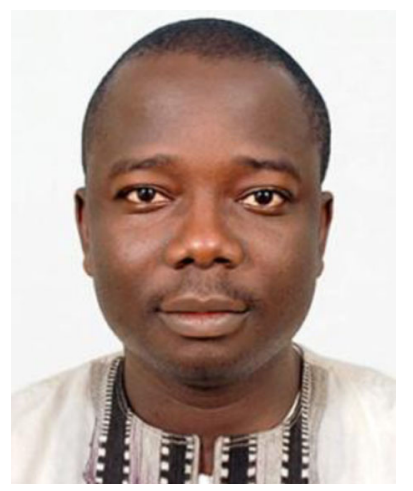

Achille Assogbadjo is an agronomist and forester with special interests in wild edible plants and wild relatives of crop species. His doctorate is in Applied Biological Sciences and he is Professor and Researcher at the Faculty of Agronomic Sciences, University of Abomey-Calavi, Republic of Benin. He teaches conservation genetics, forest ecology, ethnobotany and domestication of forest genetic resources used by indigenous people. He belongs to more than 10 international scientific groups and is Young Affiliate of the World Academy of Sciences. To date, he has been granted more than 20 research prizes and three international prizes. His scientific research since 2000 has yielded more than 70 scientific publications in peer-reviewed international journals, books and proceedings of scientific conferences. He has attended more than 50 international conferences and training workshops. He is a native French speaker and has a good command of English.

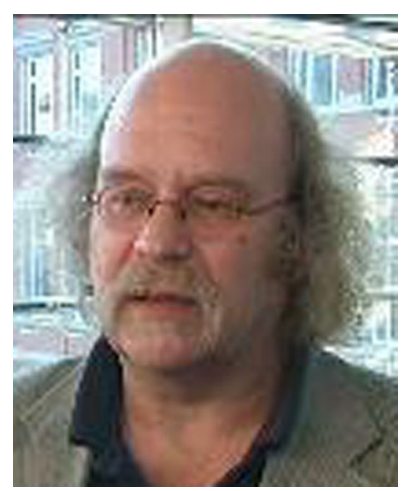

Prof. Patrick Van Damme has an MSc a degree in tropical agriculture and $\mathrm{ahD}$ in ecophysiology/ stress physiology. He was an associate expert with FAO in plant protection, and has been a professor in tropical and subtropical agronomy and ethnobotany at Ghent University, Belgium, since 1992. Since mid-2012, he has also been teaching at Prague University of Life Sciences, Faculty of Tropical AgriSciences, Czech Republic. He is senior advisor for ICRAF's domestication programme, and has been personal advisor for the Minister of Agriculture of Ecuador (2010 2012 period) for agrobiodiversity matters. Since 2008, he has been director of the Centre for Sustainable Development of Ghent University. His subjects for research and student mentoring concentrates on ethnobotany, new crop development, value chains, ecosystem services, sustainable rural development, food policy and microfinance.

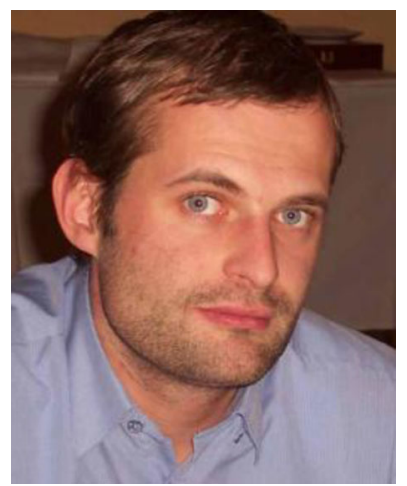

Prof. C. Lachat is at the Department of Food Safety and Food Quality, Ghent University Belgium. His research focuses on assessment of dietary intake, epidemiology, nutrition policies and public health nutrition with a particular emphasis on low and middle-income countries. Specifically, his research aims to develop effective approaches to promote healthy diets in vulnerable populations such as children and adolescents. Within this context, his research portfolio comprises a wide array of epidemiological approaches, including observational studies, evidence synthesis and intervention studies. Within Africa, Prof. Lachat has been actively involved in nutrition research in populations in Tanzania, Benin, Senegal and Ethiopia. With his colleagues at the Institute of Tropical Medicine in Belgium, he recently led a consultative process to develop and identify a sustainable nutrition research agenda in sub-Saharan Africa and a review of policies in low and middle income countries to prevent diet related chronic diseases. 